
RESEARCH AND DEVELOPMENT

\author{
http://journal.unnes.ac.id/sju/index.php/higeia
}

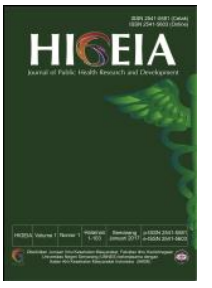

\title{
Maya Index dan Karakteristik Lingkungan Area Rumah dengan Kejadian Demam Berdarah Dengue
}

\author{
Annisa Arum Kartika Dewi ${ }^{1 凶}$, Dyah Mahendrasari Sukendra ${ }^{1}$ \\ ${ }^{1}$ Jurusan Ilmu Kesehatan Masyarakat, Fakultas Ilmu Keolahragaan, Universitas Negeri Semarang, Indonesia
}

\section{Info Artikel}

Sejarah Artikel:

Diterima 6 Agustus 2018

Disetujui 17 Oktober

2018

Dipublikasikan 30

Oktober 2018

\section{Keywords:}

DHF, Home Environment,

Maya Index

DOI

https://doi.org/10.15294

/higeia.v2i4.24699

\begin{abstract}
Abstrak
Pada tahun 2017 IR DBD sebesar 124,3 per 100.000 penduduk. Tujuan penelitian ini adalah untuk mengetahui hubungan antara maya index dan karakteristik lingkungan area rumah dengan kejadian DBD di daerah endemis DBD Kelurahan Kadipiro Kota Surakarta. Jenis penelitian ini adalah analitik observasional dengan rancangan penelitian case control. Sampel sebesar 45 kasus dan 45 kontrol dengan teknik pengambilan sampel yaitu purposive sampling. Instrumen yang digunakan adalah lembar pengukuran dan lembar observasi, kuesioner, roll meter dan dokumen rekam medik. Data dianalisis secara univariat untuk mendeskripsikan semua variabel penelitian dan secara bivariat dengan uji chi-square dan perhitungan Odds Ratio(OR). Penelitian dilakukan pada bulan Mei-Juni 2018. Hasil penelitian ini adalah maya index $(p=0,408)$, keadaan TPA terbuka $(p=0,036)$, ventilasi rumah tanpa kawat kassa $(p=0,135)$, keberadaan pakain yang menggantung $(p=0,021)$, kepadatan hunian $(p=0,168)$, jarak antar rumah $(p=1,000)$, keberadaan pekarangan kosong $(p=0,047)$, keberadaan tempat minum unggas $(p=1,000)$. Kesimpulan dari penelitian ini adalah ada hubungan antara keadaan TPA terbuka, keberadaan pakaian menggantung, keberadaan pekarangan kosong dengan kejadian DBD.
\end{abstract}

\begin{abstract}
In 2017 the dengue fever was 124.3 per 100,000 population. The purpose of this study is to determine the relationship between the maya index and environmental characteristics of the home area with the incidence of DHF in endemic area of DHF Kadipiro Surakarta. Type of research was analytic observasional with research design case control. Samples of 45 cases and 45 controls by sampling technique that is purposive sampling. The instruments used are measurement sheets and observation sheets, questionnaires, roll meters and medical record documents. Data were analyzed univariat to describe all research variables and bivariate with test chi-square and calculation Odds Ratio. The study was conducted in May-June 2018. The results of this study were maya index( $p=0.408)$, open landfill conditions $(p=0,036)$, homeless house ventilation $(p=0,135)$, the existence of hanging clothes $(p=0,021)$, occupancy density $(p=0,168)$ distance between homes $(p=1,000)$, the existence of empty $\operatorname{yard}(p=0,047)$, existence of poultry drinking place $(p=1,000)$. The conclusion, there is a relationship between the open landfill conditions, the existence of hanging clothes, the existence of empty yard with the incidence of DHF.
\end{abstract}

(C) 2018 Universitas Negeri Semarang

Alamat korespondensi:

p ISSN 1475-362846

Gedung F5 Lantai 2 FIK Unnes

e ISSN 1475-222656

Kampus Sekaran, Gunungpati, Semarang, 50229

E-mail: annisaarumkd@gmail.com 


\section{PENDAHULUAN}

Penyakit Demam Berdarah Dengue (DBD) adalah penyakit yang disebabkan oleh virus Dengue yang tergolong Arthropod-Borne Virus, genus Flavivirus, dan famili Flaviviridae. DBD ditularkan melalui gigitan nyamuk dari genus Aedes, terutama Aedes aegypti atau Aedes albopictus. Penyakit DBD dilaporkan telah menjadi masalah kesehatan bagi masyarakat Indonesia. Puskesmas Gambirsari memiliki kasus tertinggi sebanyak 206 kasus. Didapatkan IR Puskesmas Gambirsari sebesar 387,6 per 100.000 penduduk dan CFR sebesar 1\%. Pada tahun 2017 jumlah kasus di Puskesmas Gambirsari sebanyak 68 kasus, dengan IR 124,3 per 100.000 penduduk, masih menjadi yang tertinggi di Kota Surakarta.

Penderita infeksi virus dengue ditemukan dalam jumlah yang banyak di wilayah kerja Puskesmas Gambirsari, walaupun angka kematian telah dapat ditekan tetapi penyakit ini masih menjadi masalah kesehatan masyarakat, untuk itu tindakan pencegahan dan pengendalian penyakit DBD sangat perlu dilakukan untuk menekan kasus DBD di wilayah kerja Puskesmas Gambirsari. Upaya pengendalian penyakit DBD yang telah dilakukan di wilayah kerja Puskesmas Gambirsari adalah program penyuluhan kepada masyarakat, pemberian abate kepada masyarakat, gerakan Pemberantasan Sarang Nyamuk (PSN) dengan menekankan kegiatan $3 \mathrm{M}$ plus, Pemeriksaan Jentik Berkala yang dilakukan oleh kader kesehatan tingkat RT dan RW, Penyelidikan Epidemiologi (PE) bila ada kasus, fogging sesuai standar operasional prosedur serta program Sentolop (Sendiri, Tokoh Masyarakat, Lokasi, Puskesmas) yang merupakan program inovasi dari Puskesmas Gambirasari, makna dari Sentolop adalah dalam rangka gerakan pemberantasan sarang nyamuk dengan $3 \mathrm{M}$ Plus sendiri, tokoh masyarakat berkewajiban untuk mengingatkan warga agar melaksanakan Perilaku Hidup Bersih dan Sehat (PHBS), cek lokasi sekitar dan membersihkan semua tempat atau barang yang berpotensi sebagai sarang nyamuk, dan melaporkan ke puskesmas bila menemukan warga yang sakit DBD dengan dukungan surat keterangan dari rumah sakit/dokter yang menyatakan diagnosis DBD.

Keberhasilan kegiatan PSN DBD dapat diukur dengan Angka Bebas Jentik (ABJ), apabila ABJ lebih atau sama dengan 95\% diharapkan penularan DBD dapat dicegah atau dikurangi (Kemenkes RI, 2010). ABJ Kelurahan Kadipiro Kota Surakarta pada tahun 2017 yaitu sebesar $>95 \%$ itu berarti program PSN di Kelurahan Kadipiro sudah bisa dikatakan berhasil, namun untuk kepadatan vektor berdasarkan indikator Density Figure (DF) bahwa House Index (HI) 4,63\% termasuk dalam kategori kepadatan jentik sedang. Indikator kepadatan jentik (HI, CI, BI) belum cukup sebagai pertimbangan data lingkungan yang terkait dengan bionomik vektor (Rokhmawanti, 2015). Bionomik adalah hubungan antara aktivitas dan perilaku nyamuk dalam kesehariannya dengan lingkungan. Kondisi lingkungan merupakan kondisi atau tingkat kebersihan setiap wilayah yang mencerminkan kemungkinan peningkatan populasi nyamuk Aedes. Oleh sebab itu, diperlukan juga data lingkungan yang terkait dengan segi bionomik vektor yaitu Maya Index. Maya Index adalah indikator baru untuk mengidentifikasi suatu area berisiko sebagai tempat perkembangbiakan nyamuk Aedes yang didasarkan pada status kebersihan lingkungan yaitu HRI (Hygiene Risk Index) dan ketersediaan tempat-tempat yang berpotensi sebagai tempat perkembangbiakan nyamuk yaitu BRI (Breeding Risk Index) Miller et. al, 1992 dalam (Purnama \& Baskoro, 2012). Berdasarkan penelitian Purnama \& Baskoro (2012) menunjukan bahwa maya index memiliki hubungan dengan kejadian DBD.

Faktor-faktor yang mempengaruhi terjadinya suatu penyakit yaitu host, agent dan lingkungan. Penularan DBD tidak hanya karena populasi vektor yang berubah-ubah dan terus berkembang, akan tetapi sanitasi lingkungan rumah juga memberikan dukungan terhadap kejadian DBD. Faktor lingkungan adalah faktor utama yang menentukan dalam penularan $\mathrm{DBD}$, terutama lingkungan di area rumah. 
Karakteristik lingkungan yaitu lingkungan biologis, fisik maupun sosial yang mendukung nyamuk berkembang biak (Sarfraz, 2012). Lingkungan fisik yang terdiri dari keadaan Tempat Penampungan Air (TPA) yang terbuka, kepadatan hunian, jarak antar rumah, ventilasi rumah tanpa kawat kassa, keberadaan pakaian yang menggantung. Sedangkan untuk lingkungan biologi seperti keberadaan pekarangan kosong dan keberadaan tempat minum unggas.

Berdasarkan studi pendahuluan yang dilakukan peneliti sebanyak 33 rumah, diperoleh hasil untuk karakteristik lingkungan fisik rumah yaitu bahwa $100 \%$ responden tidak menutup Tempat Penampungan Air (TPA) di area rumah, 94\% rumah tidak memasang kawat kasa pada lubang ventilasi rumah, 55\% rumah terdapat pakaian yang menggantung. 94\% responden memiliki jarak antar rumah dengan rumah warga lain saling berhimpitan, menurut hasil penelitian Kusumaningtyas (2011) bahwa jarak antar rumah $<5 \mathrm{~m}$ ( $\mathrm{p}$ value $=0,004 \mathrm{OR}=$ 3,659 ) berhubungan dengan kejadian Dengue Haemmorrhagic Fever di wilayah kerja Puskesmas Blora. Keadaan rumah berdarkan kepadatan penghuni juga merupakan salah satu faktor yang mendukung kejadian DBD, nyamuk yang beristirahat di dalam rumah akan lebih mudah menggigit penderita yang terinfeksi virus dengue dan setelah itu akan menggigit orang yang tinggal satu rumah, sebab nyamuk bersifat multiple biters yaitu menggigit beberapa orang secara bergantian dalam waktu singkat (Ariati \& Hananto, 2011) . Menurut penelitian Lumingas (2017) bahwa kepadatan hunian berhubungan dengan kejadian Demam Berdarah Dengue di wilayah kerja Puskesmas Tanawangko (p value $=0,034$ dan $\mathrm{OR}=2,781$ ). Namun berdasarkan penelitian Toan (2014) menyatakan bahwa luas dan jumlah penghuni di dalam rumah ( $p$ value $=>0,05)$ tidak berhubungan dengan kejadian Demam Berdarah Dengue di Hanoi, Vietnam.

Berdasarkan karakteristik lingkungan biologi dari hasil studi pendahuluan ditemukan bahwa terdapat $49 \%$ rumah memiliki tempat untuk perindukan nyamuk (breeding place) berupa tempat minum unggas, dan terdapat pekarangan kosong yang tidak terawat di wilayah Kelurahan Kadipiro juga memicu tempat perindukan dan istirahat nyamuk. Hasil studi pendahuluan diperoleh $67 \%$ rumah berjarak $<100 \mathrm{~m}$ dengan pekarangan kosong yang tidak terawat. Hal ini juga berisiko pada penularan penyakit DBD karena jarak terbang nyamuk 50-100 meter (Sayono, 2016). .

Perbedaan penelitian ini dengan penelitian sebelumnya Kusumaningtyas (2011), (Naiatin) 2015, Purnama \& Baskoro (2012), Toan (2014), dan Nurrochmawati (2017) yaitu tempat dan waktu penelitian serta adanya variabel keberadaan pekarangan kosong dan keberadaan tempat minum unggas, yang belum pernah diteliti pada penelitian sebelumnya. Oleh sebab itu, penelitian ini bertujuan untuk mengetahui hubungan antara maya index dan karakteristik lingkungan area rumah dengan kejadian DBD di daerah endemis DBD Kelurahan Kadipiro Kota Surakarta.

\section{METODE}

Jenis penelitian yang digunakan dalam penelitian ini adalah analitik observasional dengan menelaah hubungan antara efek tertentu dengan faktor risiko tertentu. Rancangan penelitian yang digunakan yaitu case control. Penelitian ini menggunakan pendekatan secara retrospective. Efek (penyakit atau status kesehatan) diidentifikasi pada saat ini, kemudian faktor risiko diidentifikasi ada atau terjadinya pada waktu yang lalu (Notoatmodjo, 2010).

Teknik pengambilan sampel dengan menggunakan purposive sampling. Purposive sampling adalah teknik pengambilan sampel yang didasarkan pada suatu pertimbangan tertentu yang dibuat oleh peneliti sendiri, berdasarkan ciri atau sifat-sifat populasi yang sudah diketahui sebelumnya (Notoatmodjo, 2010). Purposive sampling adalah teknik pengambilan sampel dengan pertimbangan tertentu yang dibuat oleh peneliti sendiri, berdasarkan ciri atau sifat-sifat populasi yang sudah diketahui sebelumnya. Pertimbangan terebut berdasarkan kriteria inklusi, eksklusi dan 
pertimbangan variabel perancu yaitu mobilitas penduduk.

Sumber data dalam penelitian ini terdiri dari antara lain a) data sekunder, sumber data sekunder adalah data yang diperoleh dari laporan Dinas Kesehahtan Kota Surakarta mengenai kasus DBD. Data sekunder juga didapatkan dari data Puskesmas Gambirasari mengenai kasus DBD serta dari Kelurahan Kadipiro mengenai kewilayahan Kelurahan Kadipiro, b) data primer, yang digunakan dalam penelitian ini adalah data hasil pengukuran, observasi, dan wawancara mengenai maya index, karakeristik lingkungan fisik rumah (keadaan TPA yang terbuka, ventilasi rumah tanpa kawat kasa, keberadaan pakaian yang menggantung, kepadatan hunian, jarak antar rumah), dan karakteristik lingkungan biologi rumah (jarak terhadap pekarangan kosong, dan keberadaan tempat minum unggas) di lingkungan area rumah Kelurahan Kadipiro Kota Surakarta.

Teknik pengambilan data dalam penelitian ini adalah a) pengukuran, dilakukan untuk mengukur kepadatan hunian, jarak rumah terhadap pekarangan kosong, dan jarak antar rumah, b) observasi, digunakan untuk pengumpulan data membuktikan kebenaran mengenai keberadaan kontainer-kontainer yang berpotensi sebagai tempat perindukan nyamuk di lingkungan area rumah untuk menentukan maya index, keadaan TPA yang terbuka, jarak antar rumah, ventilasi rumah tanpa kawat kasa, keberadaan pekarangan kosong dan keberadaan tempat minum unggas, c) wawancara, dilakukan dengan cara tanya jawab dengan responden dengan menggunakan panduan wawancara berupa kuesioner atau daftar pertanyaan untuk pengumpulan data mengenai TPA yang terbuka, ventilasi rumah tanpa kawat kasa, keberadaan pakaian yang menggantung, kepadatan hunian, jarak antar rumah, keberadaan pekarangan kosong, dan keberadaan tempat minum unggas, d) dokumentasi, dengan mengumpulkan berbagai sumber tulisan yang berkenaan dengan objek penelitian, berupa data sekunder mengenai data nama dan alamat penderita DBD, IR, dan CFR dan dokumentasi digital dilakukan dengan menggunakan alat kamera digital.

Analisis data dalam penelitian ini terdiri dari, a) analisis univariat, digunakan untuk mendeskripsikan semua variabel penelitian meliputi keadaan TPA yang terbuka, ventilasi rumah tanpa kawat kasa, keberadaan pakaian yang menggantung, kepadatan hunian, jarak antar rumah, keberadaan pekarangan kosong, dan keberadaan tempat minum unggas di lingkungan area rumah Kelurahan Kadipiro Kota Surakarta, b) analisis bivariat, dalam penelitian digunakan untuk mengetahui hubungan antara variabel bebas dan variabel terikat. Uji statistik yang digunakan yaitu chisquare, bila tidak memenuhi syarat, maka digunakan uji fisher atau kolmogorov smirnov. Perhitungan Confidence Interval (CI) dengan tingkat kepercayaan $95 \%$ dan level signifikansi alfa 5\%. Perhitungan Odds Ratio (OR) untuk mengetahui besar perbandingan antara peluang terjadinya efek dengan peluang tidak terjadinya efek pada kelompok berisiko dengan kelompok tanpa risiko. Nilai OR menunjukkan besar faktor risiko terhadap kejadian DBD dengan taraf signifikansi $95 \%$ atau tingkat kesalahan $5 \%$.

\section{HASIL DAN PEMBAHASAN}

Penelitian ini dilakukan di Kelurahan Kadipiro Kota Surakarta yang merupakan wilayah kerja Puskesmas Gambirsari.

Tabel 1. Karakteristik Kasus dan Kontrol

\begin{tabular}{lcccc}
\hline Karakteristik & Kasus & $\%$ & Kontrol & $\%$ \\
\hline Jenis Kelamin & & & & \\
Laki-laki & 28 & 62,2 & 21 & 53,3 \\
Perempuan & 17 & 37,8 & 24 & 46,7 \\
Jumlah & 45 & 100,0 & 45 & 100,0 \\
\hline Umur & & & & \\
$\leq 10$ & 23 & 51,1 & 18 & 40,0 \\
$11-20$ & 14 & 31,1 & 19 & 42,2 \\
$21-30$ & 2 & 4,4 & 3 & 6,7 \\
$31-40$ & 5 & 11,1 & 4 & 8,9 \\
$>40$ & 1 & 2,2 & 1 & 2,2 \\
\hline Jumlah & 45 & 100,0 & 45 & 100,0 \\
\hline
\end{tabular}


Tabel 2. Karakteristik Responden

\begin{tabular}{|c|c|c|c|c|c|}
\hline No & Karakteristik & Responden Kasus & $\%$ & Responden Kontrol & $\%$ \\
\hline \multirow[t]{4}{*}{1.} & Jenis Kelamin & & & & \\
\hline & Laki-laki & 19 & 42,2 & 11 & 24,4 \\
\hline & Perempuan & 26 & 57,8 & 34 & 75,6 \\
\hline & Jumlah & 45 & 100,0 & 45 & 100,0 \\
\hline \multirow[t]{7}{*}{2.} & Umur & & & & \\
\hline & $\leq 10$ & 0 & 0,0 & 0 & 0,0 \\
\hline & $11-20$ & 2 & 4,4 & 3 & 6,7 \\
\hline & $21-30$ & 4 & 8,9 & 5 & 11,1 \\
\hline & $31-40$ & 24 & 53,3 & 12 & 26,7 \\
\hline & $>40$ & 15 & 33,3 & 25 & 55,6 \\
\hline & Jumlah & 45 & 100,0 & 45 & 100,0 \\
\hline \multirow[t]{7}{*}{3.} & Tingkat Pendidikan & & & & \\
\hline & Tidak sekolah & 1 & 2,2 & 2 & 4,4 \\
\hline & SD & 7 & 15,6 & 7 & 15,6 \\
\hline & SMP & 8 & 17,8 & 19 & 42,2 \\
\hline & SMA & 20 & 44,4 & 11 & 24,4 \\
\hline & PT & 9 & 20,0 & 6 & 13,3 \\
\hline & Jumlah & 45 & 100,0 & 45 & 100,0 \\
\hline \multirow[t]{9}{*}{4.} & Status Pekerjaan & & & & \\
\hline & Buruh & 4 & 8,9 & 7 & 15,6 \\
\hline & Pedagang & 8 & 17,8 & 7 & 15,6 \\
\hline & Swasta & 11 & 24,4 & 3 & 6,7 \\
\hline & Wiraswasta & 8 & 17,8 & 3 & 6,7 \\
\hline & Pegawai Negeri Sipil & 0 & 0,0 & 1 & 2,2 \\
\hline & Tidak Bekerja & 11 & 24,4 & 19 & 42,2 \\
\hline & Lain-lain & 3 & 6,7 & 5 & 11,1 \\
\hline & Jumlah & 45 & 100,0 & 45 & 100,0 \\
\hline
\end{tabular}

Berdasarkan hasil penelitian diperoleh distribusi data responden berdasarkan jenis kelamin yang disajikan dalam Tabel 2 dapat diketahui bahwa responden kasus yang berjenis kelamin laki-laki sejumlah 19 orang $(42,2 \%)$ dan yang berjenis kelamin perempuan sejumlah 26 orang $(57,8 \%)$. Sedangkan untuk responden kontrol yang berjenis kelamin laki-laki sejumlah 11 orang $(24,4 \%)$ dan yang berjenis kelamin perempuan sejumlah 75,6 orang $(60 \%)$.

Berdasarkan hasil penelitian diperoleh distribusi data responden berdasarkan umur yang disajikan dalam Tabel 2 dapat diketahui bahwa jumlah responden kasus terbanyak adalah pada usia 31 - 40 tahun sejumlah 24 orang $(53,3 \%)$ dan yang paling sedikit yaitu pada usia $\leq 10$ tahun yaitu berjumlah $0(0,0 \%)$. Sedangkan untuk responden kontrol terbanyak adalah pada usia $>40$ tahun sejumlah 25 orang $(55,6 \%)$ dan yang paling sedikit yaitu pada usia $\leq 10$ tahun yaitu berjumlah $0(0,0 \%)$.

Berdasarkan hasil penelitian diperoleh distribusi data responden berdasarkan pendidikan yang disajikan dalam Tabel 2 dapat diketahui bahwa responden kasus dengan pendidikan terakhir SMA memiliki jumlah terbanyak yaitu sebanyak 20 responden (44,4\%). Responden yang tidak sekolah memiliki jumlah paling sedikit yakni 1 responden (2,2\%). Sedangkan untuk responden kontrol terbanyak adalah pada tingkat SMP sejumlah 19 responden $(42,2 \%)$ dan yang paling sedikit yaitu responden yang tidak sekolah sejumlah 2 responden $(4,4 \%)$.

Berdasarkan hasil penelitian diperoleh distribusi data responden berdasarkan pekerjaan 
yang disajikan dalam Tabel 2, dapat diketahui bahwa status pekerjaan responden kasus terbanyak adalah tidak bekerja dan swasta masing-masing 11 orang $(24,4 \% 0$, paling sedikit adalah Pegawai Negeri Sipil sejumlah $0 \%$ Sedangkan pada responden kontrol status pekerjaan yang paling banyak adalah tidak bekerja sejumlah 19 orang (42,2\%), dan yang paling sedikit adalah Pegawai Negeri Sipil sejumlah 1 orang $(1,1 \%)$.

Berdasarkan Tabel 3 Proporsi Controllable sites (CS) pada kelompok kontrol lebih banyak daripada kasus yakni 541 buah berbanding 493 buah. Proporsi Disposable sites (DS) pada kasus lebih banyak yakni 83 buah dibandingkan dengan kontrol 44 buah. Secara keseluruhan baik kontainer Controllable sites dan Disposable sites yang ditemukan jentik lebih banyak pada kelompok kasus yakni 14 buah sedangkan kontainer kelompok kontrol yang positif jentik yaitu sebanyak 8 buah.
Jenis kontainer CS pada kasus yang paling banyak ditemukan adalah jenis pot bunga yakni sebanyak 201 buah $(40,8 \%)$, serta pada kelompok kontrol kontainer yang paling banyak ditemukan adalah ember yakni sebanyak 207 buah $(38,3 \%)$. Sedangkan yang paling banyak ditemukan jentik pada kelompok kasus dan kontrol pada jenis kontainer CS adalah bak mandi. Jenis kontainer DS pada kasus yang paling banyak ditemukan adalah jenis botol bekas yakni 35 buah, pada kelompok kontrol jenis kontainer DS yang paling banyak ditemukan adalah ember bekas yakni 16 buah. Sedangkan yang paling banyak ditemukan jentik di kontainer DS pada kelompok kasus adalah ember bekas, untuk kelompok kontrol tidak ditemukan jentik.

Dari hasil uji statistik diperoleh nilai $p=0,408 \quad(p<0,05)$ maka Ha ditolak dan Ho diterima, sehingga tidak ada hubungan antara maya index dengan kejadian Demam Berdarah

Tabel 3. Karakteristik dan Jumlah Kontainer

\begin{tabular}{|c|c|c|c|c|c|c|c|c|c|c|}
\hline \multirow{2}{*}{ No } & \multirow{2}{*}{ Jenis Kontainer } & \multicolumn{3}{|c|}{ Kasus } & \multicolumn{3}{|c|}{ Kontrol } & \multicolumn{3}{|c|}{ Total } \\
\hline & & $\sum$ & $\%$ & + jentik & $\sum$ & $\%$ & + jentik & $\sum$ & $\%$ & + jentik \\
\hline \multicolumn{2}{|c|}{ Controllable sites } & 493 & & & 541 & \multicolumn{5}{|c|}{1034} \\
\hline \multicolumn{2}{|c|}{ 1. Ember } & 163 & 33.1 & 2 & 207 & 38.3 & 2 & \multicolumn{2}{|c|}{$370 \quad 358$} & 4 \\
\hline \multicolumn{2}{|c|}{ 2. Bak ma } & 31 & 6.3 & 5 & 34 & 6.3 & 2 & 65 & $\begin{array}{c}35.8 \\
6.3\end{array}$ & 7 \\
\hline \multicolumn{2}{|c|}{ 3. Tandon Kulkas } & 10 & 2.0 & 1 & 10 & 1.8 & 1 & \multirow{2}{*}{$\begin{array}{c}20 \\
402\end{array}$} & 1.9 & 2 \\
\hline \multicolumn{2}{|c|}{$4 \quad$ Pot bunga } & 201 & 40.8 & 1 & 201 & 37.2 & 2 & & \multirow{2}{*}{$\begin{array}{c}38.9 \\
6.8\end{array}$} & \multirow{2}{*}{$\begin{array}{l}3 \\
0\end{array}$} \\
\hline \multicolumn{2}{|c|}{ 5. Tempat minum burung } & 25 & 5.1 & 0 & 45 & 8.3 & 0 & 70 & & \\
\hline \multicolumn{2}{|c|}{ 6. Tempat minum ayam } & 13 & 2.6 & 0 & 4 & 0.7 & 0 & 17 & 1.6 & 0 \\
\hline & Dispenser & 14 & 2.8 & 1 & 3 & 0.6 & 0 & 17 & 1.6 & 1 \\
\hline & Tong Air & 0 & 0.0 & 0 & 4 & 0.7 & 0 & 4 & 0.4 & 0 \\
\hline 9. & Tandon Air & 8 & 1.6 & 0 & 8 & 1.5 & 0 & 16 & 1.5 & 0 \\
\hline 10. & Drum Minyak & 0 & 0.0 & 0 & 3 & 0.6 & 1 & 3 & 0.3 & 0 \\
\hline 11. & Sumur & 4 & 0.8 & 0 & 7 & 1.3 & 0 & 11 & 1.1 & 0 \\
\hline 12. & Jerigen & 6 & 1.2 & 0 & 9 & 1.7 & 0 & 15 & 136.4 & 0 \\
\hline 13. & Gentong & 1 & 0.2 & 0 & 2 & 0.4 & 0 & 3 & 0.3 & 0 \\
\hline 14. & Galon & 17 & 3.4 & 0 & 4 & 0.7 & 0 & 21 & 2.0 & 0 \\
\hline Dispo. & able sites & 83 & & & 44 & & & 127 & & \\
\hline & Panci bekas & 1 & 1.2 & 0 & 0 & 0.0 & 0 & 1 & 0.8 & 0 \\
\hline & Kaleng bekas & 5 & 6.0 & 0 & 5 & 11.4 & 0 & 10 & 7.9 & 0 \\
\hline 3. & Ban bekas & 2 & 2.4 & 0 & 1 & 2.3 & 0 & 3 & 2.4 & 2 \\
\hline 4. & Botol bekas & 35 & 42.2 & 0 & 8 & 18.2 & 0 & 43 & 33.9 & 0 \\
\hline & Ember bekas & 28 & 33.7 & 2 & 16 & 36.4 & 0 & 44 & 34.6 & 2 \\
\hline 6. & Toples bekas & 11 & 13.3 & 0 & 14 & 31.8 & 0 & 25 & 19.7 & 0 \\
\hline 7. & Jerigen bekas & 1 & 1.2 & 0 & 0 & 0.0 & 0 & 1 & 0.8 & 0 \\
\hline Under & controllable sites & 11 & & & 10 & & & 21 & & \\
\hline 1. & Kolam ikan & 4 & 36.4 & 2 & 4 & 40.0 & 0 & 8 & 38.1 & 2 \\
\hline 2. & Aquarium & 7 & 63.6 & 0 & 6 & 60.0 & 0 & 13 & 61.9 & 0 \\
\hline Total & & & 37 & 14 & & & 8 & & 82 & 22 \\
\hline
\end{tabular}


Dengue (DBD). Keberadaan kontainer yang beragam dan sanitasi yang masih buruk merupakan faktor yang berperan dalam perkembangbiakan jentik yang memicu keberadaan jentik Aedes aegypti di lingkungan masyarakat Kelurahan Kadipiro Kota Surakarta.

Berdasarkan hasil observasi yang dilakukan oleh peneliti, didapatkan hasil bahwa jenis kontainer controllable sites yang paling banyak ditemukan di kelompok kasus adalah pot bunga sejumlah 201 buah, kedua yaitu ember sejumlah 163 buah, untuk kelompok kontrol jenis kontainer controllable sites yang paling banyak ditemukan adalah ember sejumlah 207 buah. Total positif jentik dari kelompok kasus dan kelompok kontrol paling banyak ditemukan di bak mandi.

Berdasarkan wawancara yang dilakukan oleh penliti kepada responden, bahwa masyarakat memiliki kebiasaan menampung air di beberapa ember setiap rumah, sebab sumber penyedia air di Kelurahan Kadipiro dari PDAM, airnya tidak mengalir full 24 jam dalam sehari, ketika banyak yang menggunakan, airnya hanya mengalir sedikit atau bahkan mati. Maka dari itu, masyarakat menanmpung air dalam jumlah yang banyak untuk mengantisipasi jika air tidak mengalir. Sedangkan untuk jenis kontainer disposable sites pada kelmpok kasus banyak ditemukan jenis botol bekas, sementara untuk kelompok kontrol banyak ditemukan ember bekas. Total positif jentik dari kelompok kasus dan kelompok kontrol paling banyak ditemukan di ban bekas dan ember bekas. Manajemen jenis kontainer disposable sites di Kelurahan Kadipiro yang masih perlu mendapat perhatian karena juga mempengaruhi keberadaan perkembangbiakan nyamuk Aedes aegypti. Berdasarkan perhitungan dengan indikator BRI (Breeding Risik Index) dan HRI (House Risk Index) menunjukkan hasil bahwa maya index di Kelurahan Kadipiro dalam tingkat yang sedang, menunjukkan bahwa keadaan tingkat penuluran Demam Berdarah Dengue (DBD) di Kelurahan Kadipiro dalam risiko penularan sedang. Hal ini sejalan dengan penelitian Astuti (2016) menyatakan bahwa maya index di wilayah endemis DBD Kota Tangerang Selatan yang dalam kategori sedang sehingga penularan DBD di wilayah tersebut dalam risiko penularan sedang.

Dari hasil uji statistika dengan menggunakan chi-square, diperoleh hasil p-value $0,036(<0,05)$ sehingga Ho ditolak dan Ha diterima, artinya ada hubungan yang bermakna antara keberadaan Tempat Penampungan Air (TPA) dalam keadaan terbuka dengan kejadian Demam Berdarah Dengue (DBD) di Kelurahan Kadipiro Kota Surakarta tahun 2018. Nilai Odd Ratio $(\mathrm{OR})=3,08 \quad(95 \% \quad \mathrm{CI}=1,170-8,129)$, menunjukkan bahwa sampel yang memiliki Tempat Penampungan Air (TPA) dalam keadaan terbuka mempunyai risiko 3,08 kali lebih besar menderita Demam Berdarah Dengue (DBD) daripada sampel yang memiliki Tempat Penampungan Air (TPA) dalam keadaan tertutup. Nyamuk Aedes aegypti berkembang biak di tempat penampungan air untuk keperluan sehari-hari atau barang-barang lain yang memungkinkan air tergenang dan tidak beralaskan tanah (Kemenkes RI, 2011). Menurut Anggraini \& Cahyati (2017) apabila terdapat genangan air yang dianggap aman oleh nyamuk untuk meletakkan telurnya maka di tempat itulah nyamuk betina akan meletakkan telurnya.

Berdasarkan hasil wawancara dan observasi menunjukkan bahwa responden di Kelurahan Kadipiro lebih suka menampung air dalam jumlah yang banyak untuk keperluan sehari-hari di Tempat Penampungan Air (TPA) seperti ember, bak mandi, drum ataupun tong air. Namun sebagian besar responden tidak memiliki kebiasaan untuk menutup TPA dan membiarkannya dalam keadaan terbuka dengan alas an tidak mempunyai penutup dan sebagian yang lain tidak bersedia untuk menutup.

Menurut Tsuzuki (2009), adanya tutup pada Tempat Penampungan Air (TPA) dan penggunaannya dengan benar memiliki dampak yang signifikan terhadap keberadaan larva dan pupa nyamuk Aedes aegypti dibandingkan Tempat Penampungan Air tanpa penutup. Tempat Penampungan Air (TPA) dalam keadaan tertutup sangat diperlukan supaya 
Tabel 4. Rekapitulasi Hasil Bivariat

\begin{tabular}{|c|c|c|c|c|c|c|c|c|}
\hline \multirow{2}{*}{ Variabel } & \multicolumn{2}{|c|}{ Kasus } & \multicolumn{2}{|c|}{ Kontrol } & \multirow[t]{2}{*}{$\mathrm{N}$} & \multirow[t]{2}{*}{$\%$} & \multirow{2}{*}{$\begin{array}{c}\text { OR } \\
(95 \% \mathrm{CI})\end{array}$} & \multirow{2}{*}{$\begin{array}{c}p- \\
\text { value }\end{array}$} \\
\hline & $\mathrm{n}$ & $\%$ & $\mathrm{~N}$ & $\%$ & & & & \\
\hline \multicolumn{9}{|l|}{ Maya Index } \\
\hline Tinggi & 10 & 22,2 & 6 & 13,3 & 16 & 17,8 & \multirow{2}{*}{$\begin{array}{l}1,857 \\
5,637)\end{array}$} & \multirow[t]{2}{*}{0,408} \\
\hline Sedang dan Rendah & 35 & 77,8 & 39 & 86,7 & 74 & 82,2 & & \\
\hline \multicolumn{9}{|l|}{ KeadaanTPA Terbuka } \\
\hline Buruk & 37 & 82,2 & 27 & 60,0 & 64 & 71,1 & \multirow[t]{2}{*}{$3,08(1,170-8,129)-$} & \multirow[t]{2}{*}{0,036} \\
\hline Baik & 8 & 17,8 & 18 & 40,0 & 26 & 28,9 & & \\
\hline \multicolumn{9}{|c|}{ Ventilasi Rumah tanpa Kawat Kassa } \\
\hline Buruk & 38 & 84,4 & 31 & 68,9 & 69 & 76,7 & \multirow[t]{2}{*}{$2,45(0,881-6,825)$} & \multirow[t]{2}{*}{0,135} \\
\hline Baik & 7 & 15,6 & 14 & 31,1 & 21 & 23,3 & & \\
\hline \multicolumn{9}{|c|}{ Keberadaan Pakaian Menggantung } \\
\hline Buruk & 37 & 82,2 & 26 & 57,8 & 63 & 70,0 & \multirow[t]{2}{*}{$3,38(1,170-8,129)$} & \multirow[t]{2}{*}{0,021} \\
\hline Baik & 8 & 17,8 & 19 & 42,2 & 27 & 30,0 & & \\
\hline \multicolumn{9}{|l|}{ Kepadatan Hunian } \\
\hline Padat ( $\leq 9 \mathrm{~m} 2$ /orang) & 5 & 11,1 & 11 & 24,4 & 45 & 17,8 & \multirow{2}{*}{$0,38(0,122-1,222)$} & \multirow{2}{*}{0,168} \\
\hline $\begin{array}{l}\text { Tidak padat / ideal } \\
(>9 \mathrm{~m} 2 / \text { orang })\end{array}$ & 40 & 88,9 & 34 & 75,6 & 45 & 82,2 & & \\
\hline \multicolumn{9}{|l|}{ Jarak Antar Rumah } \\
\hline Buruk $(\leq 5 \mathrm{~m})$ & 43 & 95,6 & 42 & 93,3 & 85 & 94,4 & \multirow[t]{2}{*}{$1,54(0,244-9,660)$} & \multirow[t]{2}{*}{1,000} \\
\hline $\operatorname{Baik}(>5 \mathrm{~m})$ & 2 & 4,4 & 3 & 6,7 & 5 & 5,6 & & \\
\hline \multicolumn{9}{|c|}{ Keberadaan Pekarangan Kosong } \\
\hline Buruk & 34 & 75,6 & 24 & 29,0 & 58 & 64,4 & \multirow[t]{2}{*}{$2,7(1,103-6,634))$} & \multirow[t]{2}{*}{0,0047} \\
\hline Baik & 11 & 24,4 & 21 & 46,7 & 32 & 35,6 & & \\
\hline \multicolumn{9}{|c|}{ Keberadaan Tempat Minum Unggas } \\
\hline Buruk & 14 & 31,1 & 15 & 33,3 & 29 & 32,2 & \multirow[t]{2}{*}{$0,90(0,373-2,188)$} & \multirow[t]{2}{*}{1,000} \\
\hline Baik & 31 & 68,9 & 30 & 66,7 & 61 & 67,8 & & \\
\hline
\end{tabular}

Dapat menekan jumlah nyamuk yang berkembangbiak pada kontainer.

Dari hasil uji satatistika dengan menggunakan chi-square, diperoleh hasil $\mathrm{p}$ value $0,135(>0,05)$ sehingga Ho diterima dan Ha ditolak, atinya tidak ada hubungan yang bermakna antara keberadaan ventilasi rumah tanpa kawat kassa dengan kejadian Demam Berdarah Dengue (DBD). Rumah dengan kondisi ventilasi tidak terpasang kawat kassa sangat memudahkan nyamuk untuk masuk ke dalam rumah, hal ini akan memudahkan nyamuk untuk menggigit anggota keluarga yang berada di dalam rumah, sedangkan apabila rumah dengan ventilasi yang dipasang kawat kassa dapat menghambat nyamuk untuk masuk ke dalam rumah sehingga kemungkinan nyamuk untuk menggigit semakin kecil. Hal ini sejalan dengan penelitian yang dilakukan oleh Sari (2017) di Kota Semarang menyatakan bahwa tidak ada hubungan antara pemasangan kawat kassa dengan kejadian Demam Berdarah Dengue (DBD).

Dari hasil uji statistika dengan menggunakan chi-square, diperoleh hasil pvalue $0,021(<0,05)$ sehingga Ho ditolak dan $\mathrm{Ha}$ diterima, artinya ada hubungan yang bermakna antara keberadaan pakaian yang menggantung dengan kejadian Demam Berdarah Dengue (DBD) di Kelurahan Kadipiro Kota Surakarta tahun 2018. Nilai Odd Ratio (OR) $=3,38(95 \%$ $\mathrm{CI}=1,286-8,884)$, menunjukkan bahwa sampel yang di rumahnya terdapat keberadaan pakaian yang menggantung mempunyai risiko 3,38 kali 
lebih besar menderita Demam Berdarah Dengue (DBD) daripada sampel yang di rumahnya tidak terdapat keberadaan pakaian yang menggantung. Hal ini sejalan dengan penelitian yang dilakukan oleh Sucipto (2015) bahwa kebiasaan menggantung pakaian berhubungan dengan kejadian DBD di Kabupaten Semarang dengan $p=0,001$ dan $\mathrm{OR}=8,3$.

Berdasarkan wawancara dengan responden, diketahui bahwa alasan responden menggantung pakaian di dinding atau di balik pintu karena pakaian baru dipakai sebentar dan masih layak dipakai untuk keseekoan harinya, seperti seragam sekolah, pakaian kerja, dan jaket. Hal ini memicu nyamuk Aedes aegypti masuk ke dalam rumah dan beristirahat di pakaian yang menggantung tersebut. Berdasarkan hasil penelitian diperoleh 36,7\% kasus dan kontrol berusia 11-20 tahun yang mana pada usia tersebut sedang duduk dibangku SMP atau SMA, seragam sekolah yang sudah berkeringat terkadang digantungkan di gantungan pakaian untuk keesokan hari. Pakaian menggantung di dalam rumah merupakan tempat yang disenangi oleh nyamuk Aedes aegypti untuk beristirahat. Setelah menghisap darah manusia, nyamuk akan beristirahat sambil menunggu proses pematangan telurnya. Tempat beristirahat yang disukai adalah tumbuh-tumbuhan atau benda tergantung di tempat yang gelap dan lembab berdekatan dengan tempat perkembangbiakannya (Kemenkes RI, 2011). Salah satu tempat yang disukai oleh nyamuk untuk beristirahat yaitu dalam ruangan yang terdapat benda-benda yang tergantung salah satunya adalah keberadaan pakaian yang menggantung baik di dalam rumah maupun di dalam kamar.

Dari hasil uji satatistika dengan menggunakan chi-square, diperoleh hasil $\mathrm{p}$ value $0,168(>0,05)$ sehingga Ho diterima dan Ha ditolak, atinya tidak ada hubungan yang bermakna antara kepadatan hunian dengan kejadian Demam Berdarah Dengue (DBD). Hal ini sejalan dengan penelitian penelitian Sofia (2014) yang menyatakan bahwa Hasil penelitian menunjukkan tidak ada hubungan antara kepadatan hunian di dalam rumah dengan kejadian DBD di Kabupaten Aceh Besar dengan nilai $\mathrm{p}=0,202$ dan $\mathrm{OR}=1,9(95 \% \mathrm{CI}=0,8-4,5)$. Anggota keluarga tidak seluruhnya menetap di dalam rumah sepanjang hari, misalnya karena bekerja atau bersekolah yang kegiatan tersebut dilakukan di luar rumah. Infeksi virus dengue tidak hanya terjadi di dalam rumah, namun juga dapat terjadi di tempat-tempat umum untuk beraktivitas seperti di kantor, sekolah, pasar dan tempat ibadah. Tempat-tempat tersebut juga berpotensi sebagai tempat penularan jika terdapat tempat perindukan nyamuk seperti keberadaan kontainer-kontainer atau Tempat Penampungan Air (TPA).

Dari hasil uji satatistika dengan menggunakan chi-square, diperoleh hasil pvalue $1,000(>0,05)$ sehingga Ho diterima dan Ha ditolak, atinya tidak ada hubungan yang bermakna antara jarak antar rumah dengan kejadian Demam Beradrah Dengue (DBD). Jarak rumah mempengaruhi penyebaran nyamuk dari satu rumah ke rumah yang lain, semakin dekat jarak antar rumah akan memudahkan nyamuk menyebar ke rumahrumah sebelah. Hal ini juga berisiko pada penularan penyakit DBD karena jarak terbang nyamuk 50-100 meter (Sayono \& Nurulita, 2016). Namun, pada kenyataannya tidak sesuai dengan penelitian ini. Ditemukan hasil bahwa rumah kontrol kategori buruk $(\leq 5$ meter) sebanyak 42 rumah. Penularan DBD dapat terjadi tidak hanya di lingkungan rumah, tetapi dapat terjadi di tempat-tempat umum seperti di sekolah. Berdasarkan data rekam medis dilihat dari karakteristik umur penderita DBD sebanyak $82,2 \%$ adalah usia anak sekolah $(\leq 20$ tahun). Sekolah dimungkinkan menjadi tempat yang potensial dalam penyebaran dan penularan penyakit DBD dalam penelitian ini. Dilihat dari kebiasaan menggigit nyamuk pada siang hari, bersama dengan aktivitas anak sekolah belajar di kelas.

Dari hasil uji statistika dengan menggunakan chi-square, diperoleh hasil pvalue $0,047(<0,05)$ sehingga Ho ditolak dan $\mathrm{Ha}$ diterima, artinya ada hubungan yang bermakna antara keberadaan pekarangan kosong dengan kejadian Demam Berdarah Dengue (DBD) di 
Kelurahan Kadipiro Kota Surakarta tahun 2018. Nilai Odd Ratio $(\mathrm{OR})=2,7$ (95\% CI $=1,103$ $6,634)$, menunjukkan bahwa sampel yang di rumahnya terdapat keberadaan pekarangan kosong mempunyai risiko 2,7 kali lebih besar menderita Demam Berdarah Dengue (DBD) daripada sampel yang di rumahnya tidak terdapat keberadaan pekarangan kosong. Pekarangan kosong merupakan tempat yang terdapat resting place dan breeding place untuk nyamuk Aedes aegypti karena di pekarangan kosong ditumbuhi oleh semak-semak. Keberadaan tanaman di pekarangan atau semak-semak yang rimbun berpotensi sebagai tempat istirahat nyamuk Aedes aegypti, jika berada di luar rumah.

Berdasarkan penelitian Masruroh (2016) menunjukkan hasil bahwa terdapat hubungan antara keberadaan vegetasi berhubungan dengan kejadian $\mathrm{DBD}$, dengan risiko 6 kali untuk terkena DBD daripada yang tidak memiliki vegetasi di dalam ataupun di luar rumah. Menurut penelitian Salawati (2010) menyatakan bahwa keberadaan resting place di luar rumah berhubungan dengan kejadian DBD dengan $\mathrm{p}=0,035$ dan $\mathrm{OR}=2,759$. Menurut Dinata \& Dhewantara (2012) menyatakan bahwa lahan pekarangan termasuk dalam lingkungan biologi yang mempengaruhi siklus hidup nyamuk DBD.

Di pekarangan kosong selain terdapat resting place juga terdapat breeding place seperti terdapat kontainer-kontainer yang tidak terawat yang dapat digunakan untuk nyamuk berkembangbiak. Berdasarkan penelitian Tamza (2013) menunjukkan bahwa keberadaan breeding place di dalam dan di luar rumah berhubungan dengan kejadian Demam Berdarah Dengue.

Berdasarkan hasil wawancara dan observasi bahwa di lingkungan rumah responden kasus sebagian besar terdapat pekarangan kosong yang tidak terawat karena tidak pernah dibersihkan oleh pemiliknya sebab pemiliknya tidak tinggal di Kelurahan Kadipiro atau tinggal di Kelurahan Kadipiro tetapi tidak bersedia untuk merawat dan membersihkan pekarangan kosong teresebut. Sehinga menjadi tempat yang strategis untuk perkembangbiakkan dan peristirahatan nyamuk Aedes aegypti. Berdasarkan hasil penelitian Dinata \& Dhewantara (2012) yang dilakukan di Kota Banjar bahwa keberadaan lahan pekarangan di daerah dengan endemisitas DBD tinggi (Kecamatan Banjar) lebih banyak yaitu sebesar 97,96\% daripada di dua daerah dengan endemistitas DBD sedang sebesar 95\% (Kecamatan Pataruman) dan 75\% (Kecamatan Purwaharja).

Dari hasil uji satatistika dengan menggunakan chi-square, diperoleh hasil pvalue 1,000 $(>0,05)$ sehingga Ho diterima dan Ha ditolak, atinya tidak ada hubungan yang bermakna antara keberadaan tempat minum unggas dengan kejadian Demam Beradrah Dengue (DBD). Hasil penelitian ini sesuai dengan penelitian yang telah dilakukan oleh Sukowinarsih \& Cahyati (2010) menyatakan bahwa tidak terdapat hubungan yang bermakna antara keberadan jentik pada tempat minum burung dengan kejadian DBD di wilayah kerja Puskesmas Sekaran, Kota Semarang.

Berdasarkan wawancara bahwa responden yang memiliki tempat kandang unggas sebagian besar setiap hari mengganti air minum burung sehingga dapat menekan keberadaan jentik di dalam tempat minum burung. Secara tidak langsung, responden telah melakukan pengendalian DBD dengan cara mengganti air pada tempat minum burung setiap hari. Tempat minum burung merupakan salah satu jenis kontainer yang dapat dikendalikan oleh manusia, apabila tempat minum burung diganti setiap hari maka dapat mengurangi risiko keberadaan jentik di dalam tempat minum burung.

\section{PENUTUP}

Berdasarkan hasil penelitian yang telah dilakukan, dapat diketahui bahwa ada hubungan antara keadaan TPA terbuka, keberadaan pakaian menggantung, keberadaan pekarangan kosong dengan kejadian DBD. Sementara maya index, ventilasi rumah tanpa kawat kassa kepadatan hunian, jarak antar 
rumah, keberadaan tempat minum unggas tidak berhubungan dengan kejadian DBD.

Pada penelitian ini, peneliti belum meneliti hubungan mobilitas penduduk dengan kejadian DBD di Keluahan Kadipiro sehingga diharapkan ada penelitian lebih lanjut dari penelitian ini mengenai hubungan mobilitas penduduk dengan kejadian DBD di Kelurahan Kadipiro. Serta dapat meneliti di tempat-tempat umum yang berisiko penularan DBD seperti di sekolah, pasar, tempat ibadah, dan tempat kerja.

\section{DAFTAR PUSTAKA}

Anggraini, T. S., \& Cahyati, W. H. 2017. Perkembangan Aedes aegypti pada Berbagai $\mathrm{pH}$ Air dan Salinitas Air. HIGEIA (Journal of Public Health Research and Development), 1(3): 1-10.

Ariati, Y., \& Hananto, M. 2011. Hubungan Tempat Penampungan Air Minum dan Faktor Lainnya dengan Kejadian DBD di Provinsi DKI Jakarta dan Bali. Media Litbang Kesehatan, 21(2): 55-61.

Astuti, E. P., Prasetyowati, H., \& Ginanjar, A. 2016. Risiko Penularan Demam Berdarah Dengue berdasarkan Maya Indeks dan Indeks Entomologi di Kota Tangerang. Media Litbangkes, 26(4): 211-218.

Dinata, A., \& Dhewantara, P. W. 2012. Karakteristik Lingkungan Fisik, Biologi, dan Sosial di Daerah Endemis DBD Kota Banjar Tahun 2011. Jurnal Ekologi Kesehatan, 11(4): 315-326.

Kemenkes RI. 2010. Demam Berdarah Dengue Tahun 1968-2009. Buletin Jendela Epidemiologi DBD, 2: 1-14 .

Kemenkes RI. 2011. Modul Pengendalian Demam Berdarah Dengue. Jakarta: Kemenkes RI

Kusumaningtyas, S. 2011. Hubungan Kondisi Lingkungan Fisik dan Keberadaan Jentik Aedes aegypti dalam kontainer dengan Kejadian Dengue Haemmorrhagic Fever (DHF) di Wilayah Kerja Puskesmas Blora. Skripsi. Semarang: Universitas Diponegoro

Lumingas, E. R., Kaunang, W. P. J., \& Asrifuddin, A. 2017. Faktor-aktor yang Berhubungan dengan Kejadian Demam Berdarah Dengue di Wilayah Kerja Puskesmas Tanawangko. Media Kesehatan (E-Journal Health), 9(3): 1-11.

Masruroh, L., Wahyuningsih, N. E., \& Dina, R. A. 2016. Hubungan Faktor Lingkungan dan Praktik Pemberantasan Sarang Nyamuk (PSN) dengan Kejadian Demam Berdarah
Dengue (DBD) di Kecamatan Ngawi. Jurnal Kesehatan Masyarakat, 4(4): 992-1001.

Notoatmodjo, S. 2010. Metodologi Penelitian Kesehatan. Jakarta: Rineka Cipta

Purnama, S. G., \& Baskoro, T. 2012. Maya Index dan Kepadatan Larva Aedees aegypti terhadap Infeksi Dengue. Makara Kesehatan, 16(2): 5764.

Rokhmawanti, N., Martini, \& Ginandjar, P. 2015. Hubungan Maya Index dengan Kejadian Demam Berdarah Dengue di Kelurahan Tegalsari Kota Tegal. Jurnal Kesehatan Masyarakat, 3(1): 162-170.

Salawati, T., Astuti, R., \& Nurdiana, H. 2010. Kejadian Demam Berdarah Dengue Berdasarkan Faktor Lingkungan dan Praktik Pemberantasan Sarang Nyamuk. Jurnal Kesehatan Mayarakat Indonesia, 6(2): 46-54.

Sarfraz, M., Tripathi, N., Tipdecho, T., Thongbu, T., Kerdthong, P., \& Souris, M. 2012. Analyzing the spatio-temporal relationship between dengue vector larval density and land-use using factor analysis and spatial ring mapping. BMC Public Health, 12(853), 1-19.

Sari, E., Wahyuningsih, N. E., \& Muwarni, R. 2017. Hubungan Lingkungan Fisik Rumah dengan Kejadian Demam Berdarah Dengue di Semarang. Jurnal Kesehatan Masyarakat, 5(5): 609-618.

Sayono, \& Nurulita, U. 2016. Situasi Terkini Vektor Dengue (Aedes aegypti) di Jawa Tengah. KEMAS, 11(18): 96-105.

Sofia, Suhartono, \& Wahyuningsih, N. E. 2014. Hubungan Kondisi Lingkungan Rumah dan Perilaku Keluarga dengan Kejadian Demam Berdarah Dengue Di Kabupaten Aceh Besar. Jurnal Kesehatan Lingkungan Indonesia, 13(1): 30-38.

Sucipto, P. T., Raharjo, M., \& Nurjazuli. 2015. Faktor - Faktor Yang Mempengaruhi Kejadian Penyakit Demam Berdarah Dengue ( DBD ) Dan Jenis Serotipe Virus Dengue Di Kabupaten Semarang Factors Related to The Occurence of Dengue Hemorrhagic Fever ( $\mathrm{DHF}$ ) And Dengue Virus Serotipe in Semarang District. Jurnal Kesehatan Lingkungan Indonesia, 14(2): 51-56.

Sukowinarsih, T. E., \& Cahyati, W. H. 2010. Hubungan Sanitasi Rumah dengan Angka Bebas Jentik Aedes aegypti. KEMAS, 6(1): 3035.

Tamza, R. B., Suhartono, \& Dharminto. (2013). Hubungan Faktor Lingkungan dan Prilaku 
Dengan Kejadian DBD di Wilayah Kelurahan Perumnas Way Halim Kota Bandar Lampung. Jurnal Kesehatan Masyarakat, 2(2): 1-9.

Toan, D. T. T., Hoat, L. N., Hu, W., Wright, P., \& Martens, P. 2014. Risk Factors Associated with An Outbreak of Dengue Fever/Dengue Haemorrhagic Fever in Hanoi, Vietnam. Epidemiology \& Infection, 143(8): 1594-1598.
Tsuzuki, A., Huyunh, T., \& Tsunnida, T. 2009. Effect of Exizting Practices on Reducing Aedes aegypti Pre-adults in Key Breeding Containers in Ho Chi Minh City, Vietnam. The America Society of Tropical Medicine and Hygiene, 80(5): 752-757. 